\title{
Laudatio en homenaje de D. Francisco Javier Pérez
}

\author{
Alfredo Matus Olivier* \\ Universidad de Chile y Academia Chilena de la Lengua, Chile \\ Presidente de la comisión organizadora del simposio
}

De laus y de laudare proviene laudatio 'acto de alabanza'. Gloria, laus te honor tibi sit! Así canta un antiguo himno gregoriano del 810, escrito por Teodolfo de Orleans, y cantado en el Domingo de Ramos, situación encomiástica por antonomasia. No el moriae encomion sive stultiliae laus me corresponde ejercer ahora. Encomion sapientiae es lo que me cabe emprender brevemente, con la moderación y la parvedad de los pocos minutos que se me conceden.

Alabanza del saber y de la persona que lo sustenta. No puede haber mejor laudatio, para un hombre de letras y de ciencia, como Francisco Javier Pérez, que la rigurosa, exigua y desnuda relación de su facienda. Facta linguistica es lo que exhibe este intelectual, Presidente de la Academia Venezolana de la Lengua, que ha dedicado buena parte de sus afanes al estudio del lenguaje humano y a uno de sus máximos conocedores, su ilustre conterráneo, D. Andrés Bello, polígrafo venezolano chileno a quien hoy recordamos, vale decir, traemos al corazón.

Francisco Javier Pérez ha sido reconocido como importante lexicógrafo (especialmente metalexicógrafo, diría yo), historiador de la lingüística y ensayista literario. Doctor en Historia por la Universidad Católica Andrés

Para correspondencia, dirigirse a: Alfredo Matus Olivier (amatus@uchile.cl), Universidad de Chile, Facultad de Filosofía y Humanidades, Departamento de Lingüística, Av. Capitán Ignacio Carrera Pinto 1025, Ñuñoa, Santiago, Chile. 
Bello, de la que es Profesor Titular e investigador. Ha sido investigador en importantes entidades científicas como el Centro de Estudios Latinoamericanos Rómulo Gallegos y la Universidad de Augsburgo, como colaborador del proyecto Nuevo diccionario de americanismos. Miembro de Número del Instituto de Estudios Canarios, haciendo honor a sus antepasados isleños. Miembro Correspondiente de la Real Academia Española y de la Academia Panameña de la Lengua. Miembro de la Fundación Pedro Grases y Director Académico de la Cátedra Fundacional Andrés Bello. Ha merecido diversas distinciones y galardones, entre los cuales el Premio de Ensayo "Julio César Salas". Hoy, la Universidad de Chile, la llamada Casa de Bello, lo distingue con el supremo reconocimiento, para un estudioso e investigador americanista, cual es el encargo de la "Conferencia Anual Andrés Bello 2013", sometida a examen, como corresponde a este nivel de excelencia universitaria, por un grupo de especialistas en el pensamiento y la obra del eminente polígrafo, autor de la Gramática de la lengua castellana destinada al uso de los americanos (1847).

Laus sapientiae. Alabanza de la sabiduría. Laudatio sapientiae. Elogio, encomio del saber que es rigorosamente la degustación y el sabor de las cosas (cfr. el sapere latino). Que Francisco Javier Pérez ha sabido degustar las cosas de la realidad lingüística queda demostrado y plasmado en su facienda. Pensamiento y obra quedan, como siempre, salvados de la evanescencia de la oralidad en sus publicaciones, cuantitativa y cualitativamente sustantivas. No hay monumento ni encomio de mayor perennidad. Para formarse una idea de la entidad de esta facienda, la bibliografia personal (1982-2011), acuciosamente categorizada por su autor, comprende 14 secciones, a saber: libros (23); libros en coautoría (6); folletos (4); prólogos, presentaciones, estudios preliminares, notas editoriales y epílogos (27); ediciones anotadas, compilaciones y monográficos (8); artículos en revistas científicas, en publicaciones de divulgación cultural y en diccionarios enciclopédicos (95); capítulos en libros colectivos, memorias y actas de congresos (30); artículos en periódicos (42); columnas periodísticas (188); reseñas (45), resúmenes (17), textos en contratapas (4); y un libro inédito. Además, reseñas, estudios, entrevistas y entradas bibliográficas sobre el autor (128). En cuanto a lo cualitativo, y concentrándonos solo en la primera sección, la de los libros, se reconocen en esta trayectoria escrita algunas líneas matrices, centros conceptuales que han definido su prestigiosa condición de especialista. Lingüística y geolingüística ("El insulto en Venezuela"); lexicografía y metalexicografía ("Estudios de lexicografía venezolana", "Descubriendo diccionarios encubiertos. Voces venezolanas en el viaje de Humboldt", "Diccionarios, discursos etnográficos, universos léxicos. Propuestas teóricas para la comprensión cultural de los diccionarios"; "Pensar y hacer el 
diccionario", "Diccionario histórico del español de Venezuela", "Glosario de glosarios de obras literarias venezolanas"); historiografía lingüística ("Historia de la lingüística en Venezuela", "Incursiones de lingüística zuliana. Una contribución para su historia", "Oídos sordos. Julio Calcaño y la historia del purismo lingüístico en Venezuela"). Una de las direcciones en que más ha desarrollado su quehacer lingüístico es en la metalexicografía y en la lexicografía. De hecho, en el apartado de "referencias sobre el autor" abundan las que destacan la labor del experto en esta dirección científica: 35 de las 128 menciones recogidas, más de la cuarta parte, apuntan a poner de relieve el aporte de Francisco Javier Pérez a esta área de las ciencias del lenguaje. El Diccionario bibliográfico de la metalexicografía española, editado por Ignacio Ahumada, dedica 29 artículos lexicográficos a su tarea como lexicógrafo. No puedo referirme, en esta oportunidad, a la vastísima obra intelectual de este auténtico humanista del siglo XXI que, sin dispersión, y con acentuado espíritu transdisciplinario, ha realizado en sectores intrínsecamente relacionados con el lenguaje humano como la historiografía lingüística, la geolingüística, la hermenéutica cultural, el problema del purismo, la literatura, la educación idiomática, la sociolingüística, y un largo etcétera, en cada uno de los cuales se podrían nombrar importantes contribuciones suyas.

La verdadera laudatio, la competente, tiene que ser intrínsecamente ostensiva, mostrativa de la obra que ha quedado fraguada en una trayectoria compacta y lúcida como la de Francisco Javier Pérez. No hay otro ni mejor monumento, monumentum aere perennius, como el que celebraba Horacio.

No podría, pues, concluir esta esquemática presentación sin exhibir unos de sus filones intelectuales más legítimos: las obras de nuestro conferencista dedicadas a Andrés Bello, publicadas en distintos géneros discursivos y textuales, y que también trazan un foco de sus preocupaciones predilectas: "Andrés Bello y la lingüística indoeuropea" (2006), "Prólogo al Discurso de instalación de la Universidad de Chile" (2005), "Iván Jaksic y el nuevo bellismo" (2007), dirección del número monográfico sobre Andrés Bello de la revista El desafio de la historia (2010), "Andrés Bello, hoy. Entre el fariseísmo y el parricidio" (2010), "La concepción pre-estructuralista de la Gramática de Andrés Bello" (1981), "Un bellista norteamericano: Barry L. Velleman" (1989), "Andrés Bello. Lo distinto y lo mismo" (2004), "Bello y la egiptología" (2010), "Andrés Bello, orientalista" (2009), "Las ideas lingüísticas de Bello en un estudio de J. M. Portillo" (1985), "Bello y el desconsuelo" (2009), "Para Andrés Bello" (2009), "Los versos perfectos de Andrés Bello" (2009), "Andrés Bello, el otro" (2010), además de la serie de artículos "La palabra de Bello", publicada en El Ucabista, Universidad Católica Andrés Bello, Caracas, entre 2006 y 2010 y "La palabra bellista", 
en la misma revista, entre 2010 y 2011. Es decir, contenidos sobre la historia del bellismo, sobre la interpretación de sus principales textos, sobre los sustentos teóricos de sus convicciones epistemológicas, sobre el estado actual del bellismo y sus proyecciones. En todas ellas se aprecia el interés serio y el conocimiento profundo del pensamiento y la obra del ilustre fundador de la Universidad de Chile, especialmente en lo que dice relación con el tema de nuestro Simposio: "lenguaje y cultura de la emancipación". 